\title{
[03]
}

\section{Effect of Employer Brand Image on Application Intentions of Final Year Management Undergraduates: Unfolding Employer Branding Determinants}

\author{
Jayasinghe, SRM
}

\begin{abstract}
\section{Area of the Study}

As a significant determinant of the competitiveness and effectiveness of the entity, this study is to discuss what attributes of employer or determinants of Employer Branding (EB) are paramount for the attraction of final year management undergraduates towards the employer in Sri Lanka.
\end{abstract}

\section{Problem of the Study}

Theoretical and empirical gap of the knowledge available, especially in Sri Lanka with regard to determinants of $\mathrm{EB}$ which effect to the selection of future employer of the final year management undergraduates.

\section{Method of the study}

For the purpose of the study, data were collected from a randomly selected 300 final year management undergraduate students from 03 government universities in Sri Lanka by administrating a structured questionnaire, which consisted of 32 questions/statements with 7 point scale. The data analysis included the univariate and bivariate analyses.

\section{Findings of the Study}

The findings of the study are undergraduates more concern over the development, economic and social dimensions when they choose their future employer. The preference over the factors does not have significant impact based on the gender while there is significant differences of perceptions occur on factors of EB based on the level of academic achievement of the students. Furthermore the preferences over the EB factors have some differences based on the academic institution. Female students more prefer to be employed in public sector than the private sector compared to the male students.

\section{Conclusion of the Study}

It is concluded that in order to attract young talented graduates towards the employer, the organization must have a climate which fulfill the developmental, social and economic needs of the employees.

Keywords: Employer Branding, Application Intension, Job Appealing Decision, Potential employees, Corporate Image

\section{Introduction}

With the changes of the business environment in terms of economical, technological etc. competition to acquire most suitable and talented people became stiff and made the selection process more complex (Bhatt 2015; Chhabra et al. 2014; and Zavyalova 2012). As Backhaus and Tikoo (2004) every organization expects to position within existing, potential and 
stakeholders mind to acquire various benefits such as to attract and retain best talent, to collect funds required to run the business, to get benefits such as credit facilities from suppliers, to make the competition irrelevant by developing unique resources and gaining higher market share. In order to attract best talent by positioning within the potential employees, employers have to develop favorable set of characteristics within the firm which will develop favorable attitude towards the entity. As per the Collins and Stevens (2002) potential workforce mostly consider about organization based attributes such as reputation than the role specific attributes such as salaries and benefits. Hence, development and promotion of branding message by performing employer branding (EB) would highlight the organization base attributes which will attract most suitable people for the organization. As per the Chhabra et al. (2014) and Sullivan (2004) defined EB is a targeted, long-term strategy to manage the awareness and perceptions of employees and related stakeholders with regard to a particular firm. According to Throne (2004) cited in Wilden et al. (2010), the EB is a wholesome picture created within employees and respective future employees' mind of the package of psychological, economic, and functional benefits provided by employment and identified with a particular employer. Thus positive attitude over the EB by the employer will permit them to attract and retain best talent towards the organization since thorough understanding over the important attributes of the employer will make the internal employees satisfied and potential employees will perceive organization as a good place to work.

\section{Problem Background and Problem of the Study}

The amount of financial burden to the firm due to employees leaving the organization, subsequent hiring or replacement of them can be quite significant in terms of personal and organizational re-adjustments (Jacobs 2007; Thomas \& Terence 1994, cited in Bhatt 2015). The reason behind this issue is the lack of understanding within the management regarding the expectations of the young undergraduates and deprived alignment of the organizational expectations with them. Thus in order to acquire suitably qualified personnel with high potential employer should swift to have a better understanding of the expectations of the young graduates and the organizational characteristics that influence them during their job searches (Montgomery \& Ramus 2011). As per Arachchige and Robertson (2012), Berthon et al. (2005), Bhatt (2015), Chhabra et al. (2014), Rample (2014), Wilden et al. (2010) and Zavyalova (2012) learning and advancement factors, furthermore factors such as job security, company size and reputation, recognition/appreciation from management, company culture plays a significant role when deciding the job seeking intensions and behaviors of the potential employees. Hence, expenditure over the understanding, development and communication of EB can be perceived as an investment.

Further, as per the Bambacas (2010) and Levinson (2007), cited in Bhatt (2015) and Porter (1980) organizational competitive position is affected by the effectiveness of the Human Resources (HR) practices currently adhered by a particular organization and these practices are the manifestation of the company image to the potential workforce. But normally in Sri Lankan context, poor HR practices and/or inadequate communication of the company's favorable attributes prevents the company from attracting best talent towards them. Thus 
management should make secondary information readily available which is accessible by the potential employees since they are incapable of observing organizational attributes directly (Bhatt 2015). The employer selection decision which is based on false and inadequate information will make dissatisfied and ineffective workers.

Thus in order to generate satisfied and motivated workforce and to align organizational business strategies with the HR practices, proper concentration over the development of organizational attributes which are valued by the potential employees is utmost important (Figurska \& Matuska 2013). But the lack of understanding over the concept of EB by the management acts as a barrier towards achievement of these objectives. The major reason for the lack of understanding regarding the concept is non availability of purely applicable studies on EB in Sri Lankan context. Therefore, it seems that there is a gap in the theoretical and empirical knowledge available, especially in Sri Lanka with regard to determinants of EB which effect to the application intentions of the final year management undergraduates. Therefore, the research problem addressed under this study is to reveal what factors of EB affect to the application intensions of final year management undergraduates and among them what factors dominate over the decision of the students? In other words to unfold employer branding determinants within the Sri Lankan context. Also researcher intends to identify changes of these preferences based on gender and academic performance.

\section{Research Framework}

As per Arachchige and Robertson (2012), Agrawaal and Swaroop (2009), Berthon, et al. (2005), Bhatt (2015), Chhabra et al. (2014), Mette et al. (2013), Rample (2014), Wilden et al. (2010) and Zavyalova (2012) stress that based on the context and the other surrounding factors, priorities given to the each factor of EB will differ and it is a paramount important to reveal significant factors from those existing factors. Thus, the first hypothesis of the study was as follows:

$\mathrm{H}_{1}$ : All the EB factors identified in this study are not equally important.

According to Arachchige and Robertson (2012) and Bhatt (2015), age profiles moderate the preference between the selections over the factors of EB. Based on their arguments and the empirical evidence, the second hypothesis of this study was formulated as follows:

$\mathrm{H}_{2}$ : There is a significant differences of perceptions occur on EB factors based on Gender.

There are theoretical arguments and empirical evidences Arachchige and Robertson (2012) and Bhatt (2015) regarding the differences of perception over the factors of EB based on the level of academic achievement of the potential employees. Hence the third hypothesis of this study was formulated as:

$\mathrm{H}_{3}$ : There is a significant differences of perceptions occur on EB factors based on Academic Performance. 


\section{Method}

\section{Study Design}

For the purpose of collecting data, researcher used the pre-constructed model called EmpAt scale originally developed through the study conducted by Berthon et al. in 2005. Therefore the type of the design applies to this study was descriptive design rather than the casual design since the factors influencing on job appealing decision of final year undergraduates are identified through a findings of a previous scholars, hence the researcher gained a preunderstanding on the factors before the data is collected. This was a field study since the examination of the preference over the EB factors of final year management undergraduates in Sri Lanka were done within natural environmental settings and none of environmental variables were manipulated or controlled for the purpose of the study. As the study was conducted in natural environment where events normally take place and no any artificial or contrived setting was created for the purpose of the study, this is conducted within the noncontrived setting. Since this study follows a cross-sectional design the survey method was employed, and it is characterized by a structured questionnaire which was selected as the method of data collection in this study. This study was based on both primary and secondary data. In order to identify factors of $\mathrm{EB}$ and relevant dimensions searcher observed the previous scholarly articles and to gather primary data used the model which is previously developed by the Berthon, et al. in 2005[37]. To collect primary data regarding preferences over the factors of EB which affect to the application intension of final year management undergraduates, questionnaire was distributed among the sample of interest.

The survey was carried out among the sample of 300 final year management undergraduate students selected from 03 well reputed government universities in Sri Lanka. As per the Sri Lanka University Statistics (2013) there are 15 government universities scattered throughout the country and for the ease of access researcher chose the relevant sample from the universities which are in Colombo and Gampaha district. Both quota and cluster sampling methods were applied as the sampling method of this research.

\section{Measures}

For the purpose of gathering opinions of the respondents about the factors of EB, researcher developed the questionnaire based on the standard model developed by Berthon, et al. in 2005 which is known as employer attractiveness scale (EmpAt). The questionnaire was consists of 35 questions and out of them 32 were employed to assess the student's perception of the certain employer characteristics as suggested through the EmpAt model. The statements were classified in to 05 dimensions termed as Interest Value (Innovative, High quality products, Innovative products, Customer-oriented, Profitable company, Large company, Well known company, Product or service type and Values creativity), Economic Value (Above average salary, Attractive compensation package and Job security), Social Value (Appreciation from management, Fun working environment, Good relationships with supervisors, Good relationship with colleagues, Supportive colleagues, Exciting environment, Socially responsible, Happy environment, Quality of management, Honest and fair and Gives 
personal respect), Development Value (Future opportunities, Promotes self-esteem, Develops confidence, Gaining career experience, Good promotion opportunities and Offers range of experience) and Application Value (Can use university knowledge, Can teach others university knowledge and Acceptance and belonging). EmpAt destined to measure level of attraction possess by the potential employees by allowing them to rank against each statement in the model with 07 Point Likert Scales ranging from 'Not at all important to Extremely important'.

\section{Validity and Reliability}

The external reliability of the instruments employed to collect data was examined by testretest method. The internal item consistency reliability was examined with Cronbach's Alpha test. The results of test-retest coefficient and Cronbach's Alpha test are given in Table 01, which suggests that the external and internal reliability of the instrument was satisfactory.

Table 01: Results of Test-Retest and Cronbach's Alpha of the instrument

\begin{tabular}{|l|c|c|}
\hline Instrument & Test-Retest coefficient & Cronbach's Alpha coefficient \\
\hline EmpAt scale (Factors of EB) & 0.761 & 0.866 \\
\hline
\end{tabular}

The content validity of the instrument was ensured by the conceptualization and operationalization of the concepts using the available literature and by the adherence to the standard model to gather data further indirectly by the high internal consistency reliability of the instruments as denoted by the Alphas.

\section{Techniques of Data Analysis}

Primarily collected data through the questionnaire source were analyzed using the computer based statistical data analysis package, SPSS (version 16.0) for measuring validity, reliability and for testing hypotheses. The data analysis included univariate and bivariate analyses.

\section{Results}

Univariate analysis was carried out to investigate the responses for the EmpAt factors given by the final year management undergraduates. The results of the univariate analysis are given in Table 02.

Table 02: Statistics of the distribution of Employer Branding factors

\begin{tabular}{|l|r|}
\hline Valid & 220 \\
\hline Mean & 5.8726 \\
\hline Median & 5.97 \\
\hline Mode & 6.13 \\
\hline Std. deviation & 0.51828 \\
\hline Variance & 0.269 \\
\hline Skewness & -0.692 \\
\hline Std. error of skewness & 0.164 \\
\hline Kurtosis & 0.4 \\
\hline Std. error of kurtosis & 0.327 \\
\hline
\end{tabular}




\begin{tabular}{|l|r|}
\hline Minimum & 4.31 \\
\hline Maximum & 7.00 \\
\hline
\end{tabular}

As indicated by Table 02 , the mean value of the distribution is 5.8726 . It reveals the tendency of the respondents to give higher ratings for most of the EB factors. The skewness and kurtosis of the distribution is recorded as -0.692 and 0.4 , which indicate that the data recorded for the EB factors are moderately negatively skewed. The distribution with skewness between -0.5 to +0.5 is considered as approximately symmetrical, since the distribution of this research closer to this rage it is considered as not having considerable impact towards the employment of relevant mathematical models.

To investigate the preference over public and private sector, frequency distribution analysis was used and results are summarized in Table 03.

Table 03: Preference over the private or public sector

\begin{tabular}{|l|c|c|c|c|c|}
\hline Gender & $\begin{array}{c}\text { Preferred for Private } \\
\text { Sector }\end{array}$ & $\%$ & $\begin{array}{c}\text { Preferred for Public } \\
\text { sector }\end{array}$ & $\%$ & Total \\
\hline Male & 39 & 73.58 & 14 & 26.42 & 53 \\
\hline Female & 101 & 60.48 & 66 & 39.52 & 167 \\
\hline Total & 140 & & 80 & & 220 \\
\cline { 5 - 6 }
\end{tabular}

As indicated by the Table 3, 39 of males out of 53 preferred to be employed in private sector, which is $73.58 \%$ from the total male respondents while 14 preferred to be employed in public sector which is $26.42 \%$ comparatively. From the total 167 female respondents, 101 preferred to be employed in private sector while 66 preferred to be employed in public sector which is $60.48 \%$ and $39.52 \%$ respectively.

The primary objective of this study was to identify key factors of EB which determines the job appealing decision of the final year management undergraduates. For this purpose mean values of the EmpAt factors were calculated and results are summarized in Table 04 and Table 05 .

Table 04: Mean values of the EmpAt factors

\begin{tabular}{|l|r|}
\hline Item & Mean \\
\hline Recognition/appreciation from management & 6.01 \\
\hline A fun working environment & 5.70 \\
\hline Provides opportunity for better jobs in the future & 6.40 \\
\hline Feeling good about yourself as a result of working for the organization & 6.19 \\
\hline Feeling more self-confident as a result of working for the organization & 6.22 \\
\hline Gaining experience that will help your career & 6.44 \\
\hline Having a good relationship with your superiors & 6.26 \\
\hline Having a good relationship with your colleagues & 5.99 \\
\hline Supportive and encouraging colleagues & 6.03 \\
\hline
\end{tabular}


ISSN: 2012-7227

\begin{tabular}{|l|r|}
\hline Working in an exciting environment & 5.32 \\
\hline Innovative employer-new work practices and ideas & 5.87 \\
\hline The organization values and makes use of your creativity & 5.96 \\
\hline The organization produces high quality products and services & 5.60 \\
\hline The organization produces innovative products and services & 5.50 \\
\hline Good promotion opportunities within the organization & 6.25 \\
\hline Socially responsible organization & 5.85 \\
\hline Opportunity to apply what was learned at university & 5.87 \\
\hline Opportunity to teach others what you have learned at university & 5.58 \\
\hline Acceptance and belonging & 5.88 \\
\hline The organization is customer-oriented & 5.45 \\
\hline Job security within the organization & 6.30 \\
\hline Can gain experience in a range of departments & 5.71 \\
\hline Happy work environment & 6.16 \\
\hline An above average basic salary & 6.02 \\
\hline An attractive overall compensation package & 6.12 \\
\hline Profitability of the company & 5.73 \\
\hline Company size & 5.21 \\
\hline Awareness of the company through advertising and media & 5.21 \\
\hline Type of product and/or service produced & 5.19 \\
\hline Honesty and fairness towards the employees and society & 5.89 \\
\hline Respect from family and friends as a result of being an employee of the \\
particular organization & 5.92 \\
\hline Quality of the management of functions and the management team & 6.06 \\
\hline
\end{tabular}

As per Table 04, most and least preferred EB factors are summarized in Table 05,

Table 05: Most and least preferred EB factors

\begin{tabular}{|l|l|}
\hline Level of Preference & Factors \\
\hline Most preferred EB factors & Gaining experience that will help your career \\
\cline { 2 - 3 } & Provides opportunity for better jobs in the future \\
\cline { 2 - 2 } & Job security within the organization \\
\cline { 2 - 2 } & Having a good relationship with your superiors \\
\cline { 2 - 2 } & Good promotion opportunities within the organization \\
\cline { 2 - 2 } & Feeling more self-confident as a result of working for the organization \\
\cline { 2 - 2 } & Feeling good about yourself as a result of working for the organization \\
\cline { 2 - 2 } & Happy work environment \\
\cline { 2 - 2 } & An attractive overall compensation package \\
\cline { 2 - 2 } & Quality of the management of functions and the management team \\
\hline in ascending order) & \\
\hline & Can gain experience in a range of departments \\
\cline { 2 - 2 } & A fun working environment \\
\cline { 2 - 2 } & The organization produces high quality products and services \\
\cline { 2 - 3 } & Opportunity to teach others what you have learned at university \\
\hline
\end{tabular}




\begin{tabular}{|l|l|}
\hline \multirow{4}{*}{} & The organization produces innovative products and services \\
\cline { 2 - 2 } & The organization is customer-oriented \\
\cline { 2 - 2 } & Working in an exciting environment \\
\cline { 2 - 2 } & Company size \\
\cline { 2 - 2 } & Awareness of the company through advertising and media \\
\cline { 2 - 2 } & Type of product and/or service produced \\
\hline
\end{tabular}

For the purpose of providing more clear understanding regarding the types of factors which have an impact over the job appealing decision of the final year management undergraduates, factor analysis was employed to reveal the important types of factors by reduction of data. There are three steps of the factor analysis as generation of correlation matrix, extraction of the initial solution and finally rotation of the factors. As per the Cohen's criterion, in correlation matrix, all the 32 factors of EB have 0.3 or more correlation with at least one other factor but not more than 0.9. Which indicate that it is unnecessary to drop items since each factor have an adequate level of correlation to be part of the construct. Also the KaiserMeyer-Olkin (KMO) value and Bartlett's test value's significance level are 0.847 and 0.000 respectively. Which indicate that sample is adequate and correlation matrix is an identity matrix. Hence, the factor model is feasible to reveal the core factors of EB.

Above initial solution was extracted to identifying the factors which explain most of the variance in the observed variables. It was extracted using the principle component method with the Eigen values over 1.5. Table 06 depicts the results of the extraction of an initial solution using the principle component analysis.

Table 06: Results of the principle component analysis

Total Variance Explained

\begin{tabular}{|c|c|c|c|c|c|c|c|c|c|}
\hline \multirow[b]{2}{*}{ Commonent } & \multicolumn{3}{|c|}{ Initial Eigenvalues } & \multicolumn{3}{|c|}{ Extraction Sums of Squared Loadings } & \multicolumn{3}{|c|}{ Rotation Sums of Squared Loadings } \\
\hline & Total & Wof Variance & Cumulative \% & Total & Kof Variance & Cumulative $\%$ & Total & Kofvariance & Cumulative $\%$ \\
\hline 1 & 9.583 & 29.946 & 29.946 & 9.583 & 29.946 & 29.946 & 5.742 & 17.943 & 17.943 \\
\hline 2 & 3.127 & 9.772 & 39.718 & 3.127 & 9.772 & 39.718 & 3933 & 12.292 & 30.236 \\
\hline 3 & 2.253 & 7.041 & 46.759 & 2.253 & 7.041 & 46.759 & 3.263 & 10.198 & 40.433 \\
\hline 4 & 1.917 & 5989 & 52.749 & 1.917 & 5.989 & 52.749 & 2.789 & 8.717 & 49.150 \\
\hline 5 & 1.547 & 4.836 & 57.584 & 1.547 & 4.836 & 57.584 & 2.699 & 8.434 & 57.584 \\
\hline
\end{tabular}

As per the results of Table 06, component 01 has the Eigen value of 9.583 and explains $29.946 \%$ of the total variance. Likewise factor 02, 03, 04 and 05 has Eigen values of 3.127, $2.253,1.917$ and 1.547 respectively. Thus, altogether these factors define $57.584 \%$ of the total variance in the 32 original variables. Through the rotation of factors using Varimax rotation technique, important factors and relevant dimensions which are paramount to the job appealing decision was identified and the results are given in Table 07. 
ISSN: 2012-7227

Table 07: Rotated component matrix

\begin{tabular}{|c|c|c|c|c|c|}
\hline & \multicolumn{5}{|l|}{ Component } \\
\hline & 1 & 2 & 3 & 4 & 5 \\
\hline Recognition/appreciation from management & 661 & .000 & .104 & -.013 & .155 \\
\hline A fun working environment & .547 & .042 & .117 & -.107 & .024 \\
\hline $\begin{array}{l}\text { Provides opportunity for better jobs in the } \\
\text { future }\end{array}$ & .679 & -.025 & .142 & -.070 & .295 \\
\hline $\begin{array}{l}\text { Feeling good about yourself as a result of } \\
\text { working for the organization }\end{array}$ & .709 & .061 & .224 & -.016 & .126 \\
\hline $\begin{array}{l}\text { Feeling more self-confident as a result of } \\
\text { working for the organization }\end{array}$ & .544 & .065 & .295 & -.072 & .292 \\
\hline $\begin{array}{l}\text { Gaining experience that will help your } \\
\text { career }\end{array}$ & .480 & .036 & -.006 & .066 & .266 \\
\hline $\begin{array}{l}\text { Having a good relationship with your } \\
\text { superiors }\end{array}$ & .395 & .214 & .338 & .051 & .189 \\
\hline $\begin{array}{l}\text { Having a good relationship with your } \\
\text { colleagues }\end{array}$ & .617 & .480 & .177 & .074 & -.175 \\
\hline Working in an exciting environment & .385 & .347 & .030 & -.012 & .273 \\
\hline $\begin{array}{l}\text { Innovative employer-new work practices } \\
\text { and ideas }\end{array}$ & .237 & .290 & .555 & -.143 & .124 \\
\hline $\begin{array}{l}\text { The organization values and makes use of } \\
\text { your creativity }\end{array}$ & .396 & .445 & .119 & .040 & .464 \\
\hline $\begin{array}{l}\text { The organization produces innovative } \\
\text { products and services }\end{array}$ & .079 & .867 & .132 & .062 & .067 \\
\hline $\begin{array}{l}\text { Good promotion opportunities within the } \\
\text { organization }\end{array}$ & .494 & .338 & .247 & .225 & -.006 \\
\hline Socially responsible organization & .147 & .668 & .150 & .171 & .196 \\
\hline $\begin{array}{l}\text { Opportunity to apply what was learned at } \\
\text { university }\end{array}$ & .133 & .124 & .086 & .171 & .809 \\
\hline $\begin{array}{l}\text { Opportunity to teach others what you have } \\
\text { learned at university }\end{array}$ & .126 & .244 & .025 & .170 & .778 \\
\hline Acceptance and belonging & .213 & .086 & .442 & .018 & .587 \\
\hline The organization is customer-oriented & -.248 & .626 & .273 & .019 & .210 \\
\hline Job security within the organization & .621 & .299 & .077 & .044 & .118 \\
\hline $\begin{array}{l}\text { Can gain experience in a range of } \\
\text { departments }\end{array}$ & .211 & .410 & .403 & .328 & .084 \\
\hline Happy work environment & .575 & .148 & .484 & .142 & -.059 \\
\hline An above average basic salary & .582 & -.071 & .072 & .477 & -.220 \\
\hline An attractive overall compensation package & .702 & -.009 & .076 & .356 & -.115 \\
\hline Profitability of the company & .325 & .349 & .232 & .551 & -.154 \\
\hline Company size & .006 & .156 & -.056 & .834 & .169 \\
\hline $\begin{array}{l}\text { Awareness of the company through } \\
\text { advertising and media }\end{array}$ & -.117 & .001 & .235 & .826 & .232 \\
\hline Type of product and/or service produced & -.096 & .191 & .359 & .528 & .309 \\
\hline $\begin{array}{l}\text { Honesty and fairness towards the employees } \\
\text { and society }\end{array}$ & .072 & .258 & .756 & .136 & .157 \\
\hline $\begin{array}{l}\text { Respect from family and friends as a result } \\
\text { of being an employee of the particular } \\
\text { organization }\end{array}$ & .269 & .072 & .735 & .148 & .122 \\
\hline Quality of the management of functions and & 277 & .032 & .661 & .303 & -.081 \\
\hline
\end{tabular}




\begin{tabular}{|l|r|r|r|r|r|}
\hline the management team & & & & & \\
\hline Supportive and encouraging colleagues & .556 & .454 & .169 & -.007 & -.011 \\
\hline $\begin{array}{l}\text { The organization produces high quality } \\
\text { products and services }\end{array}$ & .146 & .842 & .054 & .122 & .136 \\
\hline
\end{tabular}

According to the above table it is observable that developmental, social and economic dimensions dominate the preferences of the students when they are selecting their future employer while interest and application value dimensions held less importance when making this decision.

The bivariate analysis was conducted to assess the influence over the preferences of EB factors based on Gender, Level of academic achievement and based on the academic institution students were engaged in at the time of data collection.

Correlation between the preferences among the Male and Female groups is 0.815 with the 0.000 level of 2-tailed sigma value. Mean value of male and female groups are 5.69 and 5.93 respectively with the standard deviation of 0.49 and 0.32 among the male and female groups accordingly. It suggests that the preferences over the EB factors by the Male and Female groups have a strong positive relationship. Thus, there is no any significant difference between the preferences over the EB factors based on the gender. This finding further confirmed by conducting a t-test.

When it comes to the other aspect, i.e. level of academic achievement of the students, with the differences of the level of achievement students perceive factors of EB differently. The results are summarized in Table 08.

Table 08: Comparison of mean values over the EB factors based on level of academic achievement of the students

\begin{tabular}{|l|r|r|r|r|r|}
\hline $\begin{array}{l}\text { Level of Academic } \\
\text { Achievement of the Students }\end{array}$ & \multicolumn{1}{c|}{$\begin{array}{c}\text { Lowest } \\
\text { achievers }\end{array}$} & \multicolumn{1}{c|}{$\begin{array}{c}\text { Low } \\
\text { achievers }\end{array}$} & \multicolumn{1}{c}{$\begin{array}{c}\text { Lower } \\
\text { middle } \\
\text { achievers }\end{array}$} & $\begin{array}{c}\text { Upper middle } \\
\text { achievers }\end{array}$ & $\begin{array}{c}\text { High } \\
\text { achievers }\end{array}$ \\
\hline $\begin{array}{l}\text { Lowest achievers } \\
\text { (GPA: Below 2.0) }\end{array}$ & 1 & 0.063 & -0.054 & -0.256 & 0.082 \\
\hline $\begin{array}{l}\text { Low achievers } \\
\text { (GPA: 2.0-2.99) }\end{array}$ & 0.063 & 1 & 0.890 & 0.823 & 0.795 \\
\hline $\begin{array}{l}\text { Lower middle achievers } \\
\text { (GPA: 3.0-3.29) }\end{array}$ & -0.054 & 0.890 & 1 & 0.901 & 0.834 \\
\hline $\begin{array}{l}\text { Upper middle achievers } \\
\text { (GPA: 3.3-3.69) }\end{array}$ & -0.256 & 0.823 & 0.901 & 1 & 0.744 \\
\hline $\begin{array}{l}\text { High achievers } \\
\text { (GPA: 3.7 of higher) }\end{array}$ & 0.082 & 0.795 & 0.834 & 0.744 & 1 \\
\hline
\end{tabular}

Preferences of the lowest achievers do not demonstrate any significant relationship with the other groupings since the significant level is more than 0.05 while other relationships demonstrate a positive relationship with the other groups at 0.01 significant levels (02 tailed). 
As per the results of the Table 8, high achievers correlate more with lower middle at 0.834 correlation value and with low achievers at 0.795 correlation value than the upper middle achievers since correlation value is 0.744 while low achievers correlate more with lower middle at a correlation value of 0.890 and with the upper middle achievers at 0.823 correlation value than the high achievers since the correlation value is only 0.795 .

In order to assess whether there are any differences in perceptions occurs on EB factors based on academic institution students were engaged with at the time of collecting data, Pearson's correlation and t-test is conducted. As per the results, between university of Sri Jayewardenepura and University of Colombo, University of Sri Jayewardenepura and University of Kelaniya do not have significant differences on perception over the selection of the EB factors while preferences among the students of University of Kelaniya and University of Colombo shows some differences of selections of the EB factors since the 2tailed sigma value is less than 0.05 and the Leven's test for equality of variance is more than 0.05 which indicate that there is a difference in mean values between the two universities.

\section{Discussion and Conclusion}

As per the results of the exploratory factor analysis, it was found that undergraduates more concern over the development, economic and social dimensions when they choose their future employer. Hence there are statistical evidences to support to accept the first hypothesis of the study which was: all the EB factors identified in this study are not equally important. This findings are substantiated by the similar findings of the other authors such as Arachchige and Robertson (2012), Bhatt (2015), Chhabra and Sharma (2014), Rample (2014), Wilden, et al. (2010) and Zavyalova (2012) but this findings are not match with the research carried out by Agrawaal and Swaroop (2007). The controversy of the finding of this research is Agrawal and Swaroop (2007) mention that Learning and Advancement and Social and cultural factors are not much important for the application intention of the potential employees. The reasons for these diverse findings might be the cultural differences, structural differences of the sample, diverse methods employed to carry out the study and so on.

By employing the Pearson's correlation analysis, second and third hypothesizes of the study are assessed. The second hypothesis was: there is significant differences of perceptions occur on EB factors based on Gender. The statistical testing supported to accept that a preference over the EB factors between male and female groups doesn't have any significant differences. Further the scholars such as Arachchige and Robertson (2012) and Bhatt (2015) support for these finding of the study. The third hypothesis was: there is significant differences of perceptions occur on EB factors based on Academic Performance. Through the statistical calculations it was attested that there is a significant differences of perceptions occur on factors of EB based on the level of academic achievement of the students. These findings also supported by Arachchige and Robertson (2012) and Bhatt (2015) through their studies. Furthermore as a secondary objective it was assessed that whether there are perceptional differences over the EB factors based on the academic institution. As per the results acquired through the Pearson's correlation analysis and t-test, preferences over the EB factors among 
the students in University of Kelaniya and Colombo showed some differences and factors effecting to their job appealing decision is differ from the other group.

The findings of this research study shall be important on the theoretical as well as practical scenario. They are important to give a direction of thinking to the management that how to attract best talent towards them. Further this gives a clue to management the importance of existing of a climate within an organization which fulfills the requirements of the young job seekers. As an example, existence of a learning culture, flexible working hours, use digital media and social networks to attract people and implement a sound technological infrastructure within the firm, pay faire wages and salaries, decentralize decision making and more freedom on job etc. will address the requirements of the fresh graduates.

The researcher believes that since preferences over the EB factors are subjective from person to person, it is better to use qualitative approach to reveal the important factors of EB. For the achievement of more generalized findings, enriching the sample by including more students from other universities and more students from other streams is suggested. Further research studies are suggested to carryout to find out the impact of technological aspects such as social media towards the attraction of best talent towards the organization.

\section{$\underline{\text { References }}$}

i. Agrawal, RK \& Swaroop, P 2009, 'Effect of Employer Brand Image on Application Intentions of B-School Undergraduates', The Journal of Business Perspective, Vol. 13, no. 3 .

ii. Arachchige, BJH \& Robertson, A 2012, 'Business Student Perceptions of a Preferred Employer: A Study Identifying Determinants of Employer Branding', The IUP Journal of Brand Management, Vol. 8, no. 3.

iii. Backhaus, K \& Tikoo, S 2004, 'Conceptualizing and researching employer branding', Career Development International, Vol. 9, no. 5, pp. 501-517.

iv. Berthon, P, Ewing, MT \& Hah, LL 2005, 'Captivating company: Dimensions of

v. Bhatt, NJP 2015, 'Employment preferences of job applicants: unfolding employer branding determinants', Journal of Management Development, Vol. 34, no.6.

vi. Chhabra, NL, \& Sharma, S 2014, 'Employer branding: strategy for improving employer attractiveness', International Journal of Organizational Analysis, Vol. 22, no. 1 , pp. $48-60$.

vii. Chhabra, NL, \& Sharma, S 2014, 'Employer branding: strategy for improving employer attractiveness', International Journal of Organizational Analysis, Vol. 22, no. 1 , pp. $48-60$.

viii. Collins, CJ \& Stevens, CK 2002, 'The relationship between early recruitment-related activities and the application decisions of new labor-market entrants: a brand equity approach to recruitment', Journal of Applied Psychology, Vol. 87, no. 6, pp. 11211133.

ix. Figurska, I \& Matuska, E 2013, 'Employer Branding as a Human Resource Management Strategy', Human Resources Management \& Ergonomics, Vol. 7, no. 2. 
x. Jacobs, K 2007, The Rewards of Retention: Retaining Your Best and Your Brightest, PRSA (Public Relations Society of America).

xi. Mette, A, Etty, S, Nilsen, R \& Olafsen, AH 2013, 'Employer branding: employer attractiveness and the use of social media', Journal of Product \& Brand Management, Vol. 22, no. 7, pp. $473-483$.

xii. Montgomery, DB \& Ramus, CA 2011, 'Calibrating MBA job preferences for the $21^{\text {st }}$ Century', Academy of Management Learning \& Education, Vol. 10, pp. 9-26.

xiii. $\quad$ Porter, ME 1980, Competitive Advantage, The Free Press, New York.

xiv. Rampl, LV 2014, 'How to become an employer of choice: transforming employer brand associations into employer first-choice brands', Journal of Marketing Management, Vol. 30, no. 13, pp. 1486-1504.

xv. Sullivan, J 2004, 'Eight elements of a successful employment brand', ER Daily, Vol. 23, no. 2.

xvi. University Grants Commission 2014, Sri Lanka University Statistics, Sri Lanka.

xvii. Wilden, R, Gudergan, S \& Lings, I 2010, 'Employer branding: strategic implications for staff recruitment', Journal of Marketing Management, Vol. 26, no. 1/2, pp. 56-73.

xviii. Wilden, R, Gudergan, S \& Lings, I 2010, 'Employer branding: strategic implications for staff recruitment', Journal of Marketing Management, Vol. 26, no. 1/2, pp. 56-73.

xix. Zavyalova, DKE 2012, 'HRD practices and talent management in the companies with the employer brand', European Journal of Training and Development, Vol. 36, no.1, pp. $86-104$.

\begin{tabular}{ll}
\hline Jayasinghe, SRM & Department of Human Resource Management \\
& Univeristy of Sri Jayewardenepura \\
& jhrm@ sjp.ac.lk
\end{tabular}


HRM Scintilla 48

ISSN: 2012-7227 